
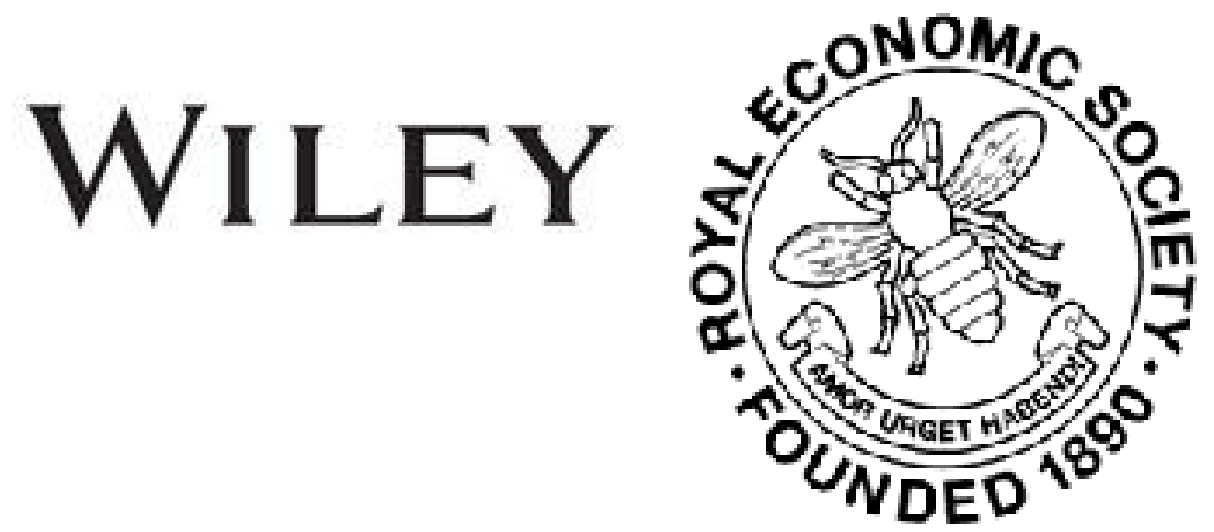

British and German Export Trade Before the War Author(s): H. H. O'Farrell

Source: The Economic Journal, Vol. 26, No. 102 (Jun., 1916), pp. 161-167

Published by: Wiley on behalf of the Royal Economic Society

Stable URL: http://www.jstor.org/stable/2222454

Accessed: 13-05-2016 11:32 UTC

Your use of the JSTOR archive indicates your acceptance of the Terms \& Conditions of Use, available at

http://about.jstor.org/terms

JSTOR is a not-for-profit service that helps scholars, researchers, and students discover, use, and build upon a wide range of content in a trusted digital archive. We use information technology and tools to increase productivity and facilitate new forms of scholarship. For more information about JSTOR, please contact support@jstor.org.

Wiley, Royal Economic Society are collaborating with JSTOR to digitize, preserve and extend access to The Economic Journal 


\section{BRITISH AND GERMAN EXPORT TRADE BEFORE THE WAR.}

THE present time would appear to be opportune for a brief comparison of British and German trade before the war. A general impression is prevalent that German progress has of late years been considerably greater than our own. It is desirable to see how far this impression is borne out by the available statistics, and whether the figures disclose an increasing severity of German competition generally, or in certain directions only.

A comprehensive survey of the trade statistics was published in Volumes IV. and VII. of the Economic JouRnaL by Mr. A. W. Flux. The inquiry was carried down to about the year 1894, and related not merely to the trade of Great Britain and Germany, but embraced also that of other Continental nations and of the United States. It is proposed in the present paper to deal only with the exports of the United Kingdom and of Germany between the years 1895 and 1913-the last year for which we possess complete information as to Germany's foreign trade.

This period of nineteen years may conveniently be grouped into averages of four periods - three of five and one of four years. The first figures to be noticed are those of the total foreign trade (exclusive of bullion), which are as follows:-

\section{Total Exports (millions of $£$ ).}

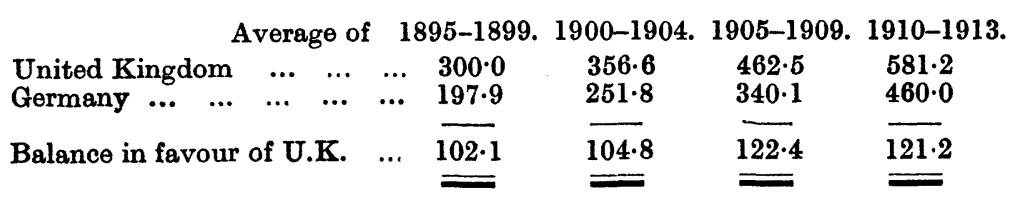

These figures, as well as those to be subsequently given, do not include the exports of the United Kingdom to Germany, or vice versa. The direct trade between the two countries has been excluded in order to deal only with competition in foreign

No. 102.--voL. XXVI. 
markets. The preponderance of British exports in the first period is really slightly greater than appears above, since the export of new ships was first included in the British statistics in the year 1899, while it found a place in the German figures two years earlier. The United Kingdom export of ships in 1899 was about nine millions in comparison with domestic exports of 255 millions, and if we assume similar proportions in the years 1897 and 1898, we shall have to add about 3 millions to the yearly average, which will thus be about 303 millions, or 105 millions in excess of the German figure.

The figures of the total trade of both countries give due weight to the re-exports, which form one of our most considerable commercial assets, and their transport is really as much a domestic industry as any other. Lacking this item, the "special exports," or exports of the domestic produce of the United Kingdom, appear in a less favourable light in comparison with those of Germany.

SPEcial Exports (domestic produce only).

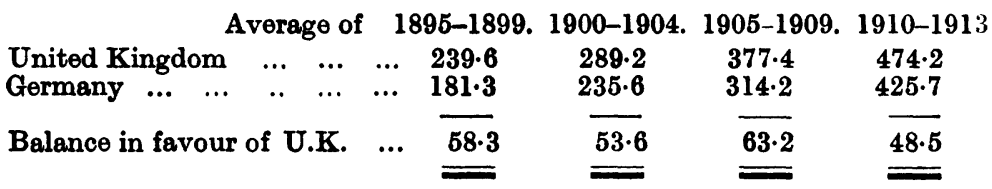

A slight correction has to be made, as before, for the export of new ships in the first period. A change in the method of recording the exports of the United Kingdom (from countries of immediate to countries of ultimate destination) has also to be taken into account. From 1904 to 1912 the Statistical Abstracts give both sets of figures, and a detailed comparison shows that the results, so far as concerns the totals that will be dealt with in this paper, are only very slightly affected. The chief alterations are a considerable fall in the exports to Belgium, almost exactly balanced by the exports to Switzerland, which appears for the first time in 1904 as one of the countries of export. The difference between the two sets of figures in no case reaches as much as a million sterling (or about a quarter of one per cent. of the total), and in most cases amounts only to one or two hundred thousand pounds.

So far the results appear to indicate that while our total exports have been pretty well maintained throughout, there has been a not inconsiderable falling behind in the case of the purely domestic exports in the last of the four periods. It is to be observed, however, that this is not due to any slackness on our 
own part-for the increase of British exports is more than maintained throughout - but to a special spurt which our rival appears to have made in the four years preceding the war. In the last year the German imports, which had reached a figure of over 525 millions in 1912 , were nearly stationary at 529 millions, but the exports increased by more than 40 millions; the imports of bullion increased by 110 millions, and the exports of bullion decreased by about 40 millions. It may be safely conjectured, I think, that the activities of the last four years were not purely commercial.

In any case, it is not sufficient to look at the figures in the lump merely. It is necessary to dissect them in order to ascertain their real significance. The first great division into which they fall is into the trade with European and non-European countries respectively. Russia will be included in the first and Turkey in the second group. Taking the European countries first, we find the figures to be as follows :-

Special (Domestic Produce) Exports to European Countries (millions of $£$ ).

\begin{tabular}{|c|c|c|c|c|}
\hline Average of & $1895-1899$ & $1900-1904$. & $1905-1909$. & $1910-1913$ \\
\hline 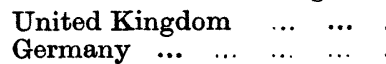 & $\begin{array}{rr}\ldots & 64 \cdot 5 \\
\ldots & 100 \cdot 3\end{array}$ & $\begin{array}{r}76 \cdot 2 \\
128 \cdot 7\end{array}$ & $\begin{array}{r}97 \cdot 4 \\
179 \cdot 6\end{array}$ & $\begin{array}{l}121 \cdot 6 \\
255 \cdot 9\end{array}$ \\
\hline Balance against the U.K. & $35 \cdot 8$ & $52 \cdot 5$ & $82 \cdot 2$ & $134 \cdot 3$ \\
\hline
\end{tabular}

The superiority and uniform progress of Germany as regards the trade with European countries is clearly indisputable.

On the other hand, when we look to the trade with the rest of the world outside the continent of Europe, we shall find a still more remarkable superiority on the side of the United Kingdom. The figures are as follows :-

\section{Special (Domestic Produce) Exports to Non-European CoUntries (millions of $£$ ).}

\begin{tabular}{|c|c|c|c|c|c|}
\hline & Average of & $1895-189$ & $1900-1904$. & 1905-1909. & $1910-1913$ \\
\hline $\begin{array}{l}\text { United Kingdom } \\
\text { Germany }\end{array}$ & $\cdots$ & .. $152 \cdot 6$ & $188 \cdot 4$ & $246 \cdot 0$ & $313 \cdot 3$ \\
\hline Germany $\quad \ldots \quad \ldots$ & $\begin{array}{ll}\cdots & \cdots\end{array}$ & $45 \cdot 3$ & $60 \cdot 7$ & $83 \cdot 5$ & $110 \cdot 4$ \\
\hline Balance in favour & of the U.I & $107 \cdot 3$ & $127 \cdot 7$ & $162 \cdot 5$ & $202 \cdot 9$ \\
\hline
\end{tabular}

The broad conclusion to be drawn from these figures would seem to be that, as regards the continent of Europe, Germany had a great superiority, obviously due to her central position and to her magnificent railway and water communications with the 
countries by which she is surrounded; while we, on the other hand, had an even greater advantage as regards the rest of the globe in our ocean communications and in the increasing magnitude and efficiency of our mercantile marine. The Continent, in the pre-war days, was becoming more and more the hinterland of the German railways, while the overseas countries of the world remained in increasing measure the sphere of influence of British sea supremacy. The contest has been between land carriage and carriage by sea, each exploiting the field most favourable to its activities.

That this was the main influence, rather than any difference of fiscal policy or of scientific attainments (though I would not for a moment minimise the importance of the latter factor), becomes, I think, still more evident if we analyse further the figures of the European trade. The Continental countries may be divided into two clearly marked groups, in one of which Germany has throughout had a greater export trade than the United Kingdom, and a second group in which British exports were, in the earlier periods, in considerable excess, and only gradually lost this preponderance. The former countries, which I shall denote by the letter "A," comprise Russia, Sweden, Norway, Denmark, the Netherlands, Belgium, Austria-Hungary, Rumania, and Switzerland. The latter, which I shall call "B" countries, include France, Portugal, Spain, Italy, Greece, and Bulgaria. It will be observed that the countries of the first group are those which march directly with Germany's frontiers, or, in the case of the Scandinavian countries, are separated only by a short stretch of the Baltic, while in the case of the others, with the exception of France, foreign territory intervenes. In the first case Germany, working-as she has worked in the war-on interior lines, has always held her own against our maritime superiority. In the latter, sea carriage at first prevailed, but lost its advantage as the European system developed and the railways of Germany were linked up with those of its neighbours by special agreements and the benefit of through rolling-stock.

The figures are as follows :-

\section{Special (Domestic) Exports to "A" Countries.}

\begin{tabular}{|c|c|c|c|c|c|c|}
\hline & verage of & & 395- 1899. & $1900-1904$. & 1905-1909. & 1910-1913. \\
\hline $\begin{array}{l}\text { United Kingdom } \\
\text { Germany } \ldots .\end{array}$ & $\begin{array}{ll}\ldots & \ldots \\
\ldots & \ldots\end{array}$ & $\begin{array}{l}\ldots \\
\ldots\end{array}$ & $\begin{array}{l}\mathbf{3 7 . 5} \\
\mathbf{8 2 \cdot 6}\end{array}$ & $\begin{array}{r}41 \cdot 8 \\
105 \cdot 0\end{array}$ & $\begin{array}{r}53 \cdot 7 \\
140.4\end{array}$ & $\begin{array}{r}68 \cdot 6 \\
195 \cdot 2\end{array}$ \\
\hline alance against $\mathrm{t}$ & e U.K. & $\ldots$ & $45 \cdot 1$ & $63 \cdot 2$ & $86 \cdot 7$ & $126 \cdot 6$ \\
\hline
\end{tabular}




\section{Special (Domestic) Exports to "B" Countries.}

\begin{tabular}{|c|c|c|c|c|}
\hline Average of & $1895-189$ & $1900-190$ & 1905-1909. & $1910-1913$ \\
\hline 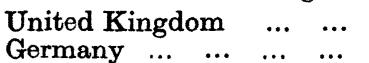 & $\begin{array}{l}\ldots \\
\ldots \\
\ldots\end{array}$ & $\begin{array}{c}34 \cdot 3 \\
23 \cdot 8\end{array}$ & $\begin{array}{l}43 \cdot 7 \\
39 \cdot 0\end{array}$ & $\begin{array}{l}52 \cdot 9 \\
60 \cdot 4\end{array}$ \\
\hline $\begin{array}{l}\text { Balance in favour of }(+) \\
\text { against }(-) \text { the U.K. }\end{array}$ & $\left.\begin{array}{l}\text { or } \\
\ldots\end{array}\right\}+\underline{+9 \cdot 3}$ & +10.5 & $\begin{array}{r}+4 \cdot 7 \\
\end{array}$ & $-7 \cdot 5$ \\
\hline
\end{tabular}

These figures seem to confirm the conclusion already arrived at, that the contest between the two countries was mainly one of land or sea carriage. During the period under review all Continental countries had greatly increased their railway systems, Germany alone having added over 7,000 miles between the years 1899 and 1912. In shipping, however, comparing the two years 1902 and 1912, she only added 950,000 tons to the register, while the United Kingdom increase was over 1,800,000 tons. The gain in effectiveness was greater still. Taking one steam ton as equivalent to four sailing tons, the German increase was a little over 1,000,000 tons and that of the United Kingdom rather more than 2,600,000 tons, or two and a-half times as great.

Another point which is noteworthy is that the trade of both countries increased pari passu throughout the period, and that neither seems on the whole to have gained at the expense of the other. Germany did not, so far as the figures disclose, oust us from any trade that we possessed before, nor we Germany. Out of an increasing volume of trade Germany obtained the major portion of the excess in Europe, Great Britain in the rest of the world. With the exception of certain years just after the South African war, and the two years of the American crisis and its aftermath (1908-09), there is no instance of a positive decline in British exports synchronising with a contrary movement in German exports. This is the more remarkable considering the strenuous efforts which Germany is well known to have been making to extend her foreign trade. The case of Turkey is a conspicuous instance. Our Consul-General noted in his report for 1908-09 (Cd. 4,446-49, p. 45) that goods were carried under the Levant tariff from Frankfort to Constantinople, via Hamburg (at which port they were transhipped), at lower rates than from Frankfort to Hamburg itself. Similar facts are given by M. Millioud ("The Ruling Caste and Frenzied Trade in Germany," 1916, pp. 109, 110) in regard to other German seaports. Yet in spite of such artificial encouragement, German exports to Turkey for the period 1910-1913 only averaged $£ 5.3$ millions, against $£ 8.5$ British.

Other overseas countries give similar results, as the following figures amply prove :- 


\begin{tabular}{|c|c|c|c|c|c|c|}
\hline & & & Britisl & ixports. & German & xports. \\
\hline & & & $1906-09$. & $1910-13$. & $1906-09$. & $1910-13$ \\
\hline To Turkey $\quad . . \quad$... & & $\ldots$ & $7 \cdot 5$ & $8 \cdot 5$ & 3.8 & $5 \cdot 3$ \\
\hline "Japan ... & $\ldots$ & $\ldots$ & $10 \cdot 8$ & $12 \cdot 2$ & $4 \cdot 5$ & $5 \cdot 4$ \\
\hline $\begin{array}{lll}\text { China } & \ldots & \ldots\end{array}$ & $\ldots$ & $\ldots$ & $10 \cdot 4$ & $11 \cdot 7$ & $3 \cdot 4$ & $4 \cdot 1$ \\
\hline "British India... & $\ldots$ & $\ldots$ & 47.6 & $56 \cdot 5$ & $5 \cdot 2$ & 5.5 \\
\hline " Canada ... & $\ldots$ & $\ldots$ & $14 \cdot 7$ & $21 \cdot 6$ & $1 \cdot 2$ & $2 \cdot 4$ \\
\hline United States & $\ldots$ & $\ldots$ & $27 \cdot 4$ & $29 \cdot 6$ & $30 \cdot 0$ & 33.5 \\
\hline Mexico ... $\ldots$ & $\ldots$ & $\ldots$ & $2 \cdot 4$ & $2 \cdot 3$ & $2 \cdot 2$ & $2 \cdot 3$ \\
\hline Brazil & $\ldots$ & $\ldots$ & $8 \cdot 6$ & $13 \cdot 3$ & $4 \cdot 7$ & 8.3 \\
\hline Australia and & New & & & & & \\
\hline & Zeal & and & $22 \cdot 8$ & 31.9 & $3 \cdot 2$ & $4 \cdot 3$ \\
\hline , Argentina & $\ldots$ & $\ldots$ & $18 \cdot 1$ & $20 \cdot 2$ & $8 \cdot 3$ & $12 \cdot 5$ \\
\hline "Chile $\quad .$. & $\ldots$ & $\ldots$ & $5 \cdot 4$ & $5 \cdot 9$ & $3 \cdot 5$ & $4 \cdot 2$ \\
\hline ", Egypt .. ... & $\ldots$ & $\ldots$ & $9 \cdot 1$ & $9 \cdot 5$ & 1.7 & $2 \cdot 0$ \\
\hline$"$ British S. Afric & a $\ldots$ & $\ldots$ & $14 \cdot 2$ & $20 \cdot 7$ & $1 \cdot 6$ & $2 \cdot 4$ \\
\hline
\end{tabular}

With the exception of the United States and Mexico, where Germany competes with us on approximately equal terms, there appears to be no non-European country in which British exports are not considerably in excess of German. The preponderance is accentuated in the case of our overseas possessions and Dominions, but is by no means confined to them. In fact, if the whole of our trade with these possessions be omitted from the British figures, leaving to Germany the benefit of her own trade with them, we shall find the British exports still in excess by an average amount of no less than 31 millions for the years 1910-13. For the years 1895-9 the excess was about 26 millons, so that it is at any rate not diminishing. If it were worth while to work out the figures for Germany's trade with our possessions, and subtract them from the German figures in order to make a fair comparison, the rate of progress would be much greater, because the trade of Germany with our Colonies has, of course, increased considerably in the interval. Apart from the Colonial preferences, no great matter in this connection, she trades with our Dominions on the same terms as ourselves, and she even exports to some of them-British West Africa, for examplemore largely than to her own adjacent territories.

The continuous trend of German exports to European and away from overseas trade may be further illustrated by the following percentage figures, compiled from the tables given in the Statistisches Jahrbuch for 1914 :-

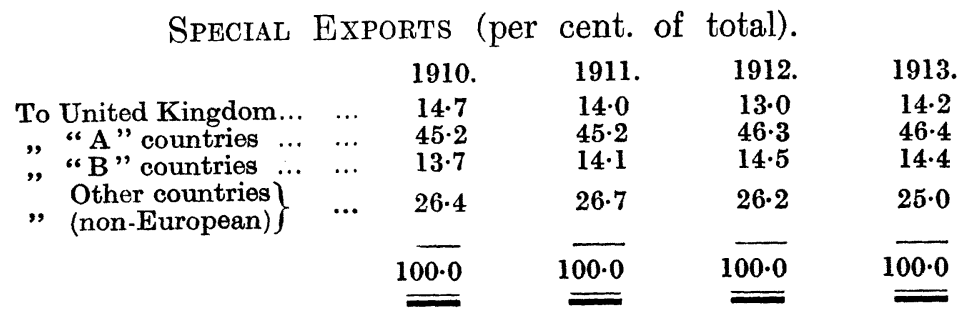


Thus, while the percentage of exports to the United Kingdom has remained nearly stationary, the proportion of exports to European countries has increased, while that to the overseas countries has declined in relation to the whole.

On the whole, the figures we have now passed in review are by no means discouraging, and it must be remembered that they reveal nothing of the quality of the trades compared. British commerce, it may safely be assumed, is always carried on with a view to more or less immediate profit. There is reason to suspect, on the other hand, that much German trade has been merely the seed-corn of a speculative harvest, destined, it may be hoped, never to mature. But taking the figures at their face value, the result would seem to be to dispel exaggerated notions of German competition. Great as German progress has been in the past, British progress has been greater. There is unquestionably much room for improvement; for better organisation, for more businesslike methods, for a larger appreciation and a more liberal endowment of research; but the vision of an all-conquering Germany has not been true in the past, and assuredly should be even less possible in the future.

H. H. O'FARRELL 